\title{
APLIKASI PENCARIAN LOKASI DAN INFORMASI TAMAN PENDIDIKAN AL-QUR'AN KOTA KUPANG BERBASIS ANDROID
}

\author{
Rudi Hariyanto ${ }^{1}$, Edwin A. Umbu Malahina ${ }^{2}$, Sumarlin $^{3}$ \\ ${ }^{123}$ STIKOM Uyelindo Kupang, Jl. Perintis Kemerdekaan, Kelurahan Kayu Putih \\ email : rhariyanto99@gmail.com, edwinariesto@gmail.com
}

\begin{abstract}
Kupang city is one of the cities in Indonesia that has a high level of religious tolerance, this is supported by the Peace Gong archipelago, but this is inversely proportional to religious education in the city of Kupang, especially the Islamic religious education because of lack of religious instruction in formal education institutions. The Qur'an Educational Park is an institution that plays an important role in providing religious education, the procedure of reading and understanding al-quran. But the lack of community knowledge about the location of the Quranic Education Park has left the public confused to find and choose the right religious education institutions to give their children education about religion. For that, there need to be built an application that can display the location and information about the Qur'an Educational Park located in the city of Kupang. With Androidbased development, it will simplify the community because Android smartphone users are quite a lot and ensure the accuracy of user location data. In addition to showing the location, the application will also provide information about the Qur'an Educational Park in Kupang City that has been marked on google maps.
\end{abstract}

Keywords: Android, Kupang City, Qur'an Educational Park, TPA, TPQ

\section{PENDAHULUAN}

Kemajuan teknologi informasi sekarang semakin luas dan sangat berkembang pesat, sehingga dapat membantu masyarakat untuk menikmati bermacam-macam kemudahan yang telah dihasilkan oleh teknologi tersebut. Salah satu aspek teknologi yang saat ini sedang berkembang pesat adalah teknologi mobile pada perangkat telepon pintar (smartphone). Teknologi smartphone yang sedang menjadi incaran masyarakat saat ini adalah adanya sistem operasi berbasis android.

Kota Kupang adalah ibukota dari Provinsi Nusa Tenggara Timur, memiliki luas wilayah $180,27 \mathrm{~km}^{2}$ serta dibatasi oleh Teluk Kupang di sebelah utara, Kabupaten Kupang di sebelah timur, Selat Semau dan Kabupaten Kupang di sebelah selatan dan di sebelah barat oleh Kabupaten Kupang. Pada tahun 2014, penduduk Kota Kupang tercatat berjumlah 384.112 jiwa, dengan jumlah penduduk beragama Islam sebesar 47.342 jiwa atau $12,33 \%$ dari keseluruh penduduk Kota Kupang ${ }^{[1]}$.

Taman Pendidikan Al-Qur'an (TPA) adalah lembaga atau kelompok masyarakat yang menyelenggarakan pendidikan nonformal jenis keagamaan Islam yang bertujuan untuk memberikan pengajaran membaca Al-Qur'an sejak usia dini, serta memahami dasar-dasar dinul Islam pada anak usia taman kanak-kanak, sekolah dasar atau bahkan yang lebih tinggi. Dengan pentingnya pemahaman agama, banyak orang tua yang ingin memasukan anaknya di Taman Pendidikan Al-Qur'an sehingga dapat membantu orang tua dalam membimbing putra-putrinya untuk meningkatkan pemahaman terhadap agama. Selain itu lemahnya sistem pendidikan agama pada jalur formal dikarenakan rendahnya jam pelajaran agama sementara bahan pengajarannya cukup luas menyebabkan pendidikan agama pada jalur formal menjadi kurang efektif. Akan tetapi karena kurangnya pengetahuan tentang lokasi Taman pendidikan Al-Qur'an membuat masyarakat kebingungan untuk memasukan putra-putrinya di Taman Pendidikan Al-Qur'an. Sehingga dibutuhkan sebuah aplikasi untuk membantu memberikan informasi mengenai lokasi-lokasi Taman Pendidikan Al-Qur'an. Aplikasi dipilih sebagai media untuk memberikan informasi agar sesuai 
dengan perkembangan jaman, sedangkan platform yang digunakan adalah android karena merupakan generasi baru platform mobile, platform ini memberikan kebebasan kepada pengembang dalam melakukan pengembangan aplikasi sesuai dengan yang diharapkannya.

Pemanfaatan GPS pada perangakat smartphone juga pernah dilakukan sebelumnya oleh Hartono ${ }^{[2]}$. yaitu aplikasi navigasi lokasi pom bensin di Jakarta berbasis Android. Penelitian ini menghasilkan sebuah mobile application yang dapat membantu pengendara bermotor mengetahui lokasi pom bensin terdekat disekitarnya dengan bantuan akses GPS pada smartphone. Selain itu Igfar ${ }^{[3]}$ juga melakukan penelitian mengenai aplikasi pencarian lokasi hotel berbasis mobile android. Penelitian ini menghasilkan aplikasi yang menunjukkan lokasi hotel terdekat dari pengguna aplikasi sehingga dapat menghemat waktu dan biaya perjalanan. Penelitianpenelitian tersebut menjadi dasar penulis untuk melakukan penelitian ini.

Hasil yang diperoleh dari penelitian ini adalah sebuah aplikasi yang dapat digunakan untuk membantu pengguna dalam memberikan informasi mengenai lokasi-lokasi Taman Pendidikan Al-Qur'an yang ada di kota Kupang berbasis Android.

Masalah dalam penelitian ini yaitu bagaimana membangun sebuah aplikasi pencarian informasi dan lokasi taman pendidikan Al-Qur'an di Kota Kupang berbasis mobile android.

Tujuan yang ingin dicapai dalam penelitian ini adalah membangun sebuah aplikasi mobile android yang dapat menampilkan informasi dan lokasi taman pendidikan Al-Qur'an di Kota Kupang yang terhubung dengan peta lokasi di google maps.

Hasil penelitian nantinya diharapkan dapat memberikan beberapa manfaat antara lain:

a. Aplikasi ini dapat mempermudah masyarakat untuk mengetahui lokasi dan jalur menuju taman pendidikan Al-Qur'an di kota Kupang.

b. Membantu masyarakat memperoleh informasi tentang Taman Pendidikan AlQur'an di kota Kupang.

c. Membantu masyarakat menentukan taman pendidikan Al-Qur'an yang cocok untuk anak-anak mereka.
Agar pembahasan masalah terarah dan tidak menyimpang dari tujuan penelitian maka berikut adalah beberapa batasan yang dibuat sebagai ruang lingkup penelitian yakni sebagai berikut:

a. Objek dalam penelitian ini adalah Taman Pendidikan Al-Qur'an yang ada di Kota Kupang.

b. Aplikasi dikhususkan untuk perangkat smartphone dengan sistem operasi Android.

c. Aplikasi memuat peta, lokasi dan informasi tentang Taman Pendidikan AlQur'an, serta jalur tempuh menuju lokasi Taman Pendidikan Al-Qur'an di kota Kupang.

\section{METODE PENELITIAN}

Metode penelitian merupakan seperangkat cara yang sistematik, logis dan rasional yang digunakan oleh peneliti ketika merencanakan, mengumpulkan, menganalisa dan menyajikan data untuk menarik kesimpulan. Metode penelitian yang akan digunakan dalam penelitian ini terdiri dari langkah-langkah berikut:

a. Studi Kepustakaan, Dilakukan dengan mencari literatur pendukung penelitian yang mampu memberikan informasi yang dibutuhkan dalam menyelesaikan penelitian ini serta membantu mempertegas teori-teori yang ada untuk menghimpun informasi yang relevan dengan topik atau masalah yang akan atau sedang diteliti. Informasi itu dapat diperoleh dari buku-buku ilmiah, karangan-karangan ilmiah dan sumbersumber tertulis baik tercetak maupun elektronik lain.

b. Observasi, dilakukan dengan cara mengadakan pengamatan langsung terhadap suatu objek yang akan diteliti terkait dengan Taman pendidikan Al-Qur'an yang ada di kota kupang, mencatat koordinat lokasi Taman Pendidikan Al-Qur'an dan informasi Taman Pendidikan Al-Qur'an dari pengelola dan masyarakat yang tinggal di sekitar lokasi Taman Pendidikan Al-Qur'an.

\section{Peralatan Penelitian}

Pada penelitian ini menggunakan alat penelitian berupa perangkat keras dan perangkat lunak, sebagai berikut: 


\section{Perangkat keras}

a. Laptop Asus X550DP-XX096D, AMD A10-5750M APU with Radeon ${ }^{\mathrm{TM}}$ HD Graphics $(2.50 \mathrm{GHz})$.

b. HDD 1 TB.

c. RAM 8 GB DDR3L.

d. Smartphone dengan OS Android minimal versi 4.3

\section{Perangkat lunak}

a. Sistem operasi Windows 8.1.

b. Android Studio sebagai IDE.

c. Bahasa pemrograman Android berbasis Java.

\section{Prosedur Analisis Data}

Dalam prosedur analisis data terdapat beberapa tahapan yang dilakukan. Sesuai dengan gambar berikut:

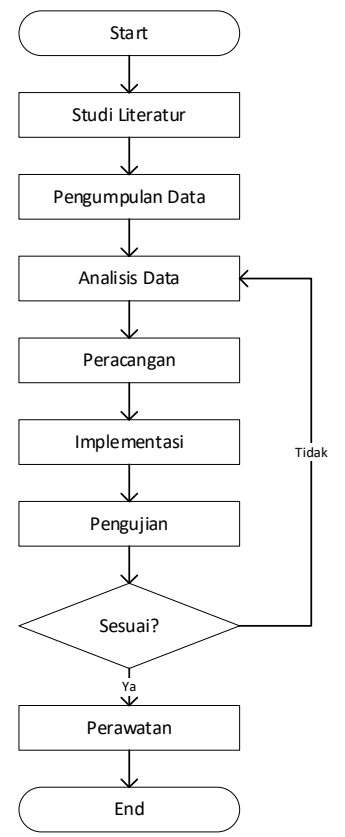

Gambar 1. Flowchart Penelitian

a. Studi literatur yaitu kegiatan yang di lakukan untuk mencari literatur pendukung penelitian yang dapat memberikan informasi dalam melakukan penelitan. Studi literatur yang di lakukan peneliti adalah dengan mencari data-data pendukung seperti buku-buku serta refrensi dari internet yang berkaitan dengan topik penelitian yang akan di lakukan, sehingga dapat membantu peneliti dalam melakukan penelitian dengan judul aplikasi pencarian lokasi dan informasi Taman Pendidikan AlQur'an di kota Kupang berbasis android.

b. Pengumpulan data merupakan kegiatan yang di lakukan oleh peneliti untuk mengumpulkan data-data yang terkait dengan penelitian. Pengumpulan data yang di lakukan peneliti adalah dengan mengumpulkan data terkait dengan Taman Pendidikan Al-Quran di kota Kupang dari penduduk di sekitar lokasi dan instansi terkait yakni Kementrian Agama kota Kupang.

c. Analisis Data merupakan kegiatan yang di lakukan guna memperoleh data yang akurat dan sesuai dengan penelitian. Analisis data di lakukan peneliti guna mencari data-data yang tepat yang akan di gunakan dalam penelitian ini.

d. Perancangan merupakan suatu teknik yang di lakukan untuk membuat rancangan dari suatu perangkat lunak. Dalam penelitian ini teknik perancangan digunakan peneliti dalam membuat rancang bangun dari penelitian yang di teliti.

e. ImplementasiImplementasi di lakukan setelah tahap perancangan. Implementasi dilakukan dengan membangun aplikasi sesuai dengan perancangan yang telah ada. Aplikasi dibangun dengan menggunakan Android Studio.

f. Pengujian dilakukan untuk mengetahui apakah sistem yang diharapkan pada aplikasi telah terpenuhi atau belum. Perangkat lunak akan diuji apakah sesuai dengan perancangan atau tidak.

g. Perawatan suatu aplikasi diperlukan, termasuk didalamnya adalah pengembangan, karena aplikasi yang dibuat tidak selamanya seperti itu. Ketika aplikasi dijalankan terdapat kemungkinan adanya kesalahan kecil yang tidak terdeteksi sebelumnya, sehingga membutuhkan perawatan atau perbaikan aplikasi dan penambahan fitur-fitur yang belum terdapat pada aplikasi tersebut.

\section{Analisa dan Perancangan Sistem}

Analisa dan perancangan sistem adalah tahapan dimana dilakukan penunangan pikiran dan perancangan sistem yang berdasarkan hasil analisis dan kebutuhan terhadap solusi dari permasalahan yang ada dengan menggunakan perangkat permodelan sistem seperti use case diagram.

\section{Prespektif produk}

Produk yang akan dikembangkan adalah sebuah aplikasi yang membantu untuk memberikan informasi mengenai lokasi-lokasi taman pendidikan Al-Qur'an (TPQ) di Kota Kupang. Selain lokasi, aplikasi juga memberikan informasi tentang jumlah 
pendidik, materi-materi yang diajarkan, biaya iuran perbulan, kontak yang dapat dihubungi dan lain-lain.

Aplikasi ini berjalan pada platform Android dan dibuat dengan bahasa pemrograman Java dengan Android Studio sebagai editor, aplikasi berjalan dengan database Firebase.

Arsitektur program ini dibagi menjadi dua yaitu arsitektur pengguna dan arsitektur admin. Arsitektur pengguna menggambarkan proses interaksi antara pengguna dan sistem untuk menampilkan informasi yang diinginkan. Pertama pengguna membuka aplikasi dan memilih data yang ingin ditampilkan, lalu aplikasi mengirimkan permintaan menuju server Firebase melalui jaringan internet, server memberikan respon dengan mengirimkan data yang diminta dan aplikasi menampilkan data tersebut.

Dalam arsitektur admin, admin dapat mengolah data melalui aplikasi, admin dapat menambah, mengubah dan menghapus data yang diinginkan, perintah tersebut dikirimkan ke server Firebase, lalu perubahan data dilakukan di server dan memberikan informasi kembali ke aplikasi bahwa data berhasil diolah.

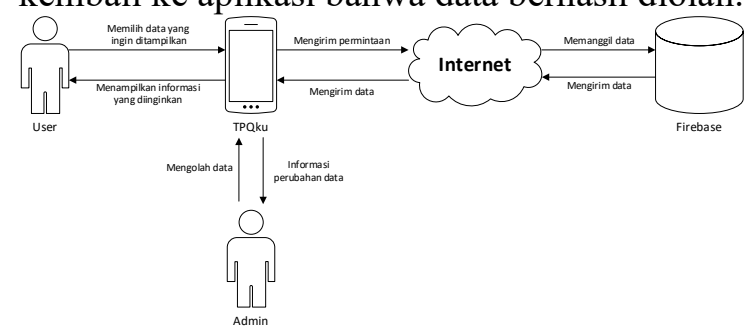

Gambar 2. Arsitektur aplikasi

\section{Kebutuhan perangkat lunak}

\section{a. Use case diagram}

Use case diagram menunjukkan sekumpulan use case, actor, dan relationship yang terjadi antara actor dan use case tersebut. Use case menggambarkan bagaimana actor berinteraksi dengan sistem. Actor adalah entitas eksternal yang memainkan peranan (role) ketika berinteraksi dengan sistem.

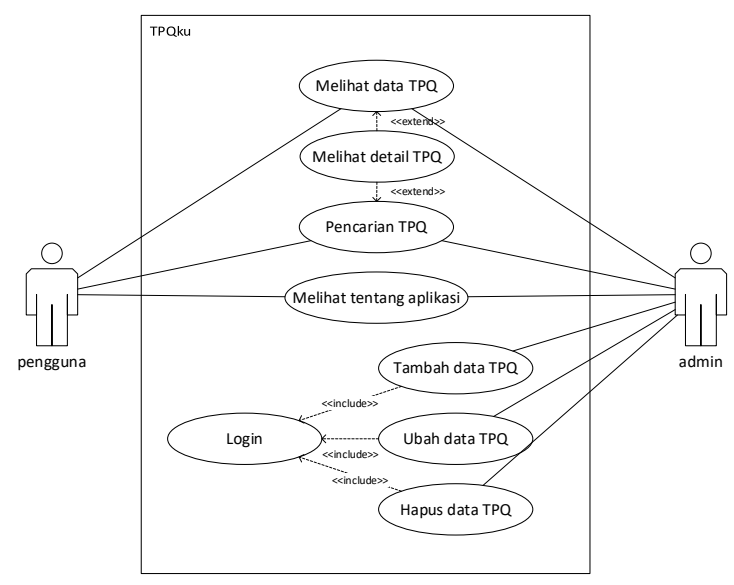

Gambar 3. Use case diagram TPQku

\section{b. Sequence diagram}

Sequence diagram adalah suatu diagram yang menggambarkan interaksi antar objek dalam sistem. Interaksi tersebut berupa pesan yang digambarkan terhadap waktu, biasanya bentuk interaksi yang terjadi berdasarkan use case view yang dibuat sebelumnya. Sequence diagram terdiri dari dimensi horizontal (objekobjek) dan dimensi vertikal (waktu). Berikut merupakan sequence diagram dari TPQku.

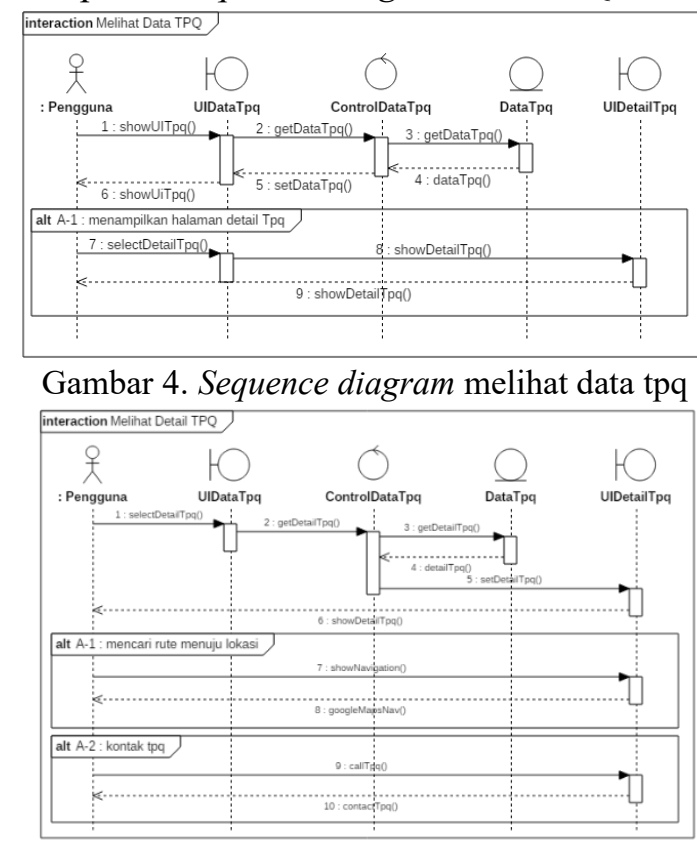

Gambar 5. Sequence diagram user melihat detail tpq

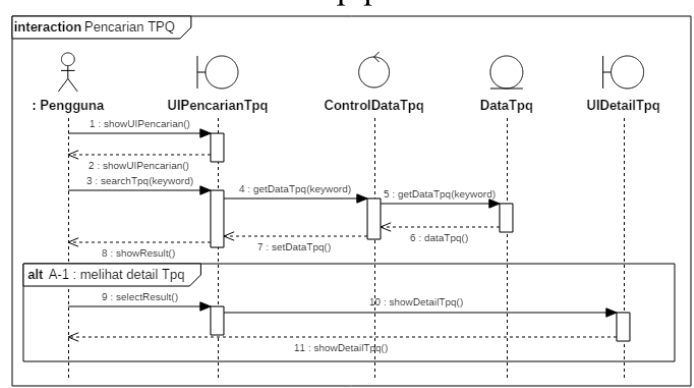

Gambar 6. Sequence diagram pencarian tpq 


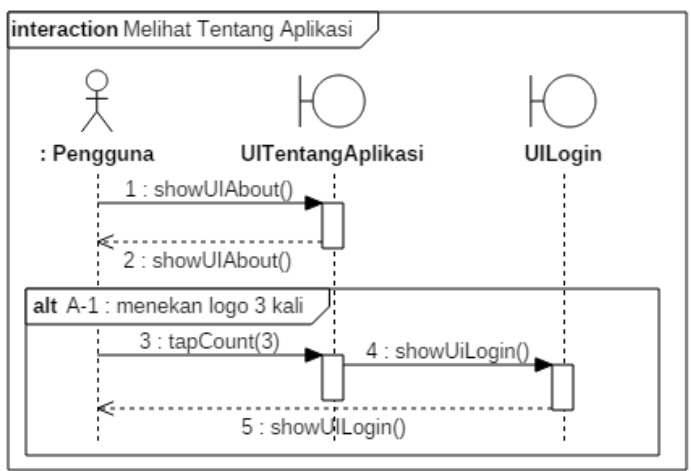

Gambar 7. Sequence diagram melihat tentang aplikasi

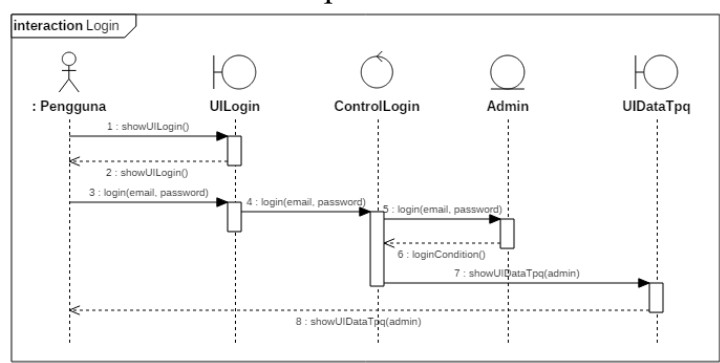

Gambar 8. Sequence diagram login

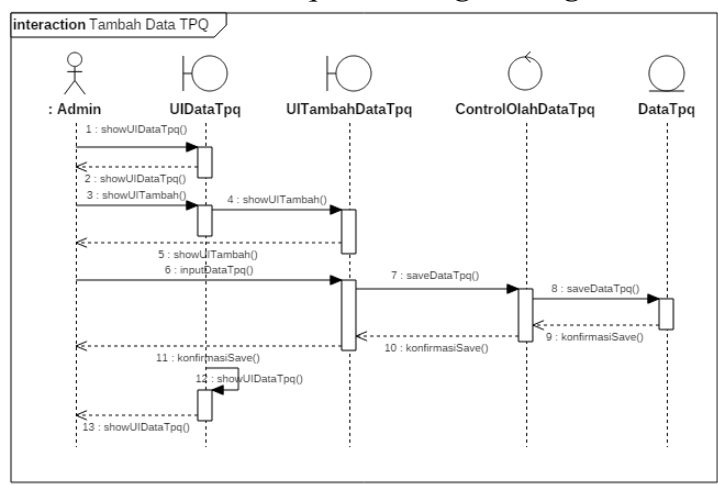

Gambar 9. Sequence diagram tambah data tpq

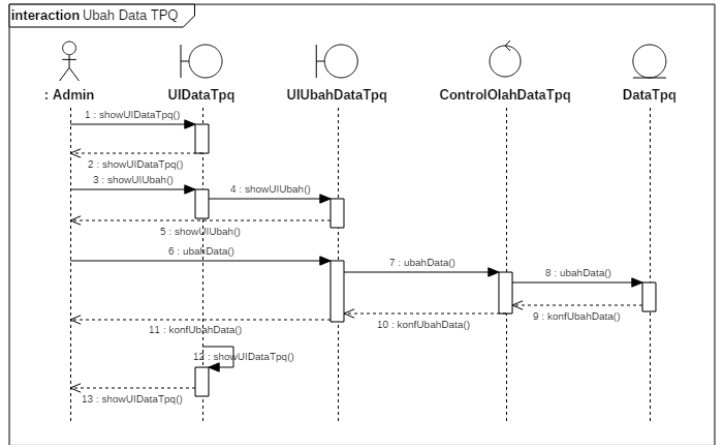

Gambar 10. Sequence diagram ubah data tpq

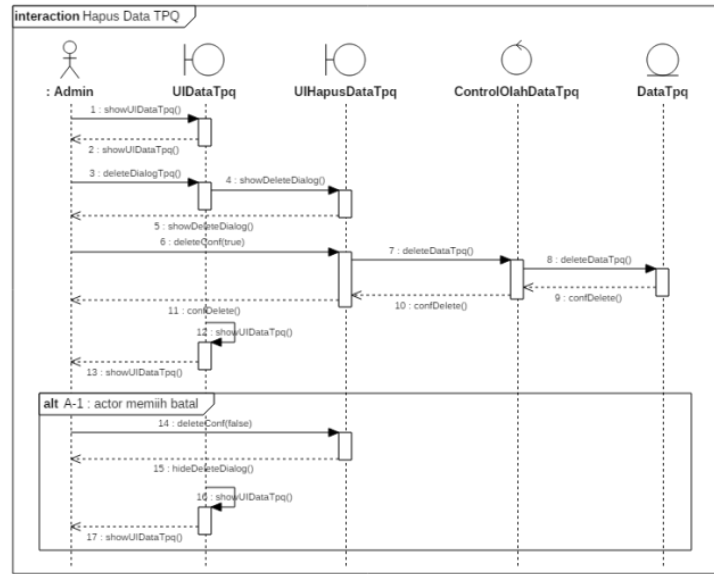

Gambar 11. Sequence diagram hapus data tpq c. Class diagram

Class diagram merupakan suatu diagram yang memperlihatkan atau menampilkan struktur dari sebuah sistem, sistem tersebut akan menampilkan sistem kelas, atribut, dan hubungan antar kelas ketika suatu sistem telah selesai. Gambaran class diagram aplikasi TPQku adalah sebagai berikut.

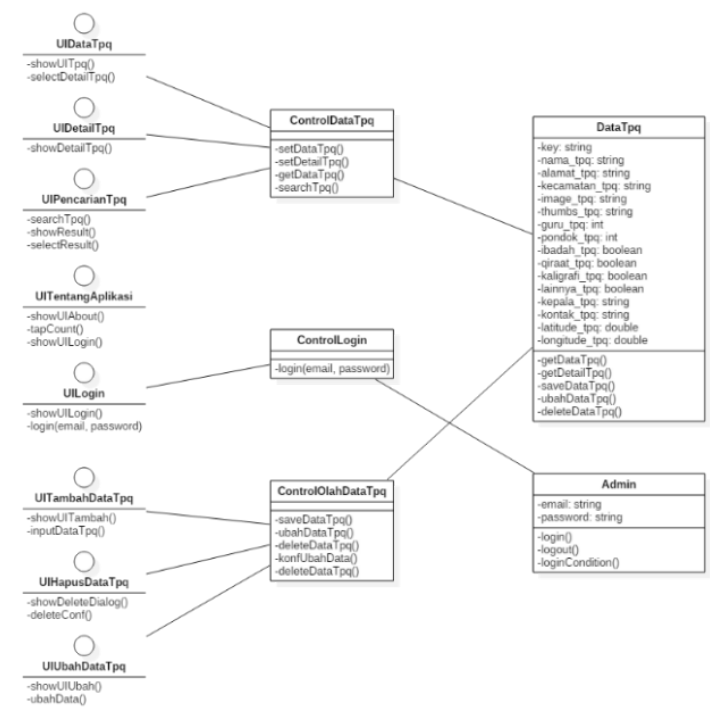

Gambar 12. Class diagram

d. Perancangan antarmuka

Perancangan antarmuka merupakan rancangan bangun dari percakapan antara pemakai dengan sistem. Percakapan yang terdiri dari proses memasukan data, menampilkan keluaran infromasi, maupun keduanya. Berikut ini adalah tampilan antarmuka yang dapat dilihat pada gambar berikut.

1) Halaman splashscreen

Halaman ini adalah halaman yang muncul pertama saat pengguna membuka aplikasi. Menampilkan logo dan nama aplikasi. 


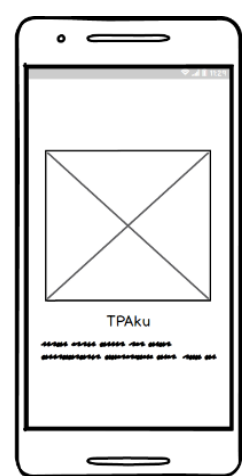

Gambar 13. Perancangan halaman splashscreen 2) Halaman data tpq

Halaman ini menampilkan informasi data tpq, informasi yang ditampilkan pada halaman ini adalah foto, nama tpq dan alamat tpq dalam cardview. Selain itu terdapat menu pencarian dan drop menu pada sisi kanan atas.

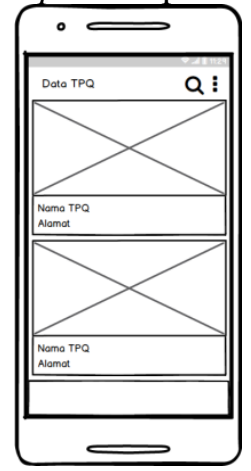

Gambar 14. Halaman data tpq

3) Halaman detail tpq

Halaman ini menampilkan informasi mengenai detail data tpq, informasi ditampilkan merupakan seluruh informasi yang dimiliki untuk tpq yang dipilih. Pengguna dapat menekan tombol navigasi untuk melihat rute menuju lokasi.

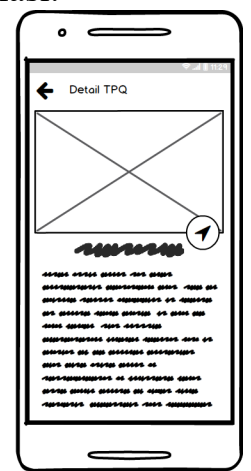

Gambar 15. halaman detail tpq

4) Halaman pencarian tpq

Halaman ini merupakan halaman yang digunakan untuk melakukan pencarian data tpq, pengguna dapat menulis kata kunci di kolom search dan sistem akan menampilkan hasil pencarian dalam bentuk cardview. Selain itu pengguna dapat menekan cardview untuk melihat detail tpq yang dipilih.

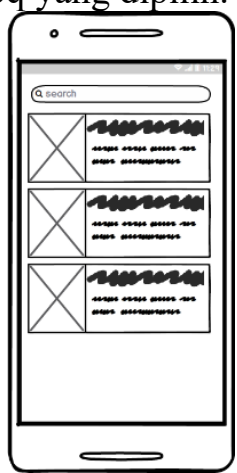

Gambar 16. Halaman pencarian tpq

5) Halama tentang aplikasi

Halaman ini menampilkan informasi mengenai aplikasi, developer, dan versi aplikasi. Selain itu jika pengguna menekan logo aplikasi sebanyak tiga kali maka akan masuk ke dalam halaman login.

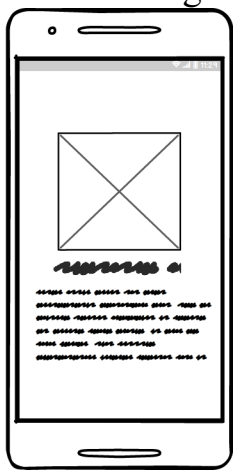

Gambar 17. Halaman tentang aplikasi

6) Halaman login

Halaman login merupakan halaman yang digunakan untuk menjadi admin dan mendapatkan akses untuk mengolah data. Pengguna harus memasukan email dan password untuk mendapatkan akses admin.

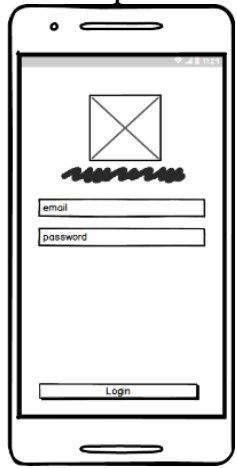

Gambar 18. Halama login

7) Halaman tambah data tpq

Halaman tambah data tpq digunakan admin untuk menambah data tpq. Pertama admin menentukan koordinat lokasi tpq, selanjutnya mengisi data sesuai form yang ada. 
Setelah pengguna menekan tombol simpan maka data akan disimpan ke dalam basis data.
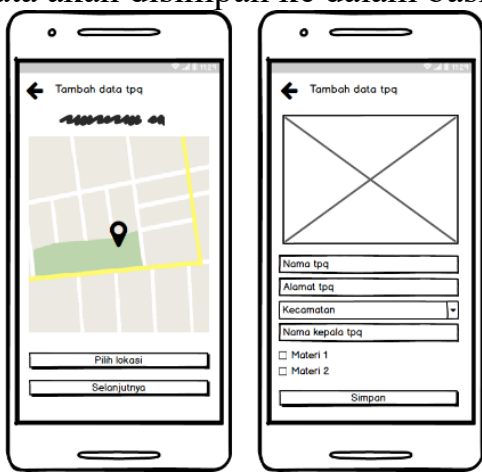

Gambar 19. Halaman tambah data tpc

8) Halaman buat data tpq

Halaman ubah data tpq digunakan untuk mengubah data tpq yang sudah pernah diinput. Data yang sebelumnya diinput akan muncul dalam form dan pengguna tinggal mengganti data yang diinginkan. Setelah itu pengguna dapat menekan tombol simpan dan sistem akan menyimpan perubahan data kedalam basis data.

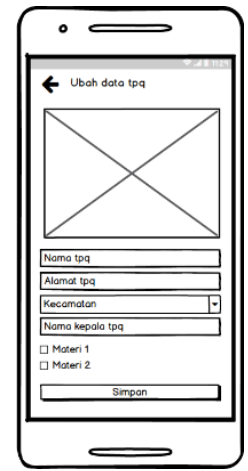

Gambar 20. Halaman ubah data tpq

9) Halaman hapus data tpq

Halaman hapus data tpq digunakan admin untuk menghapus data tpq. Akan muncul halaman konfirmasi untuk menghapus data, jika pengguna menekan tombol "ya" maka sistem akan menghapus data tersebut dari basis data, sedangkan jika pengguna menekan tombol "tidak" maka sistem akan menutup halaman hapus data dan kembali ke halaman data tpq.

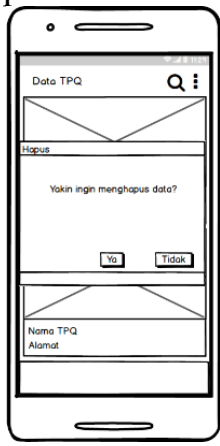

Gambar 21. Halaman hapus data tpq

\section{HASIL DAN PEMBAHASAN \\ Implementasi}

Pada tahapan ini dilakukan konversi bahasa manusia ke dalam bahasa pemrograman berdasarkan desain yang telah dibentuk sebelumnya. Bahasa pemrograman yang digunakan untuk membangun aplikasi TPQku adalah bahasa pemrograman Java. Adapun implementasinya akan dijelaskan lebih rinci sebagai berikut.

\section{Implementasi antarmuka}

Bentuk program yang dihasilkan setelah masuk ke dalam tahap implementasi dapat dilihat pada penjelasan berikut.

a. Halaman splash screen

Halaman ini adalah halaman yang muncul pertama saat pengguna membuka aplikasi. Menampilkan logo dan nama aplikasi. Berikut hasil implementasinya.

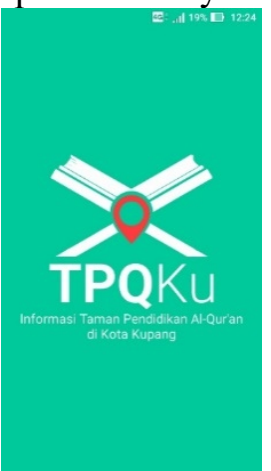

Gambar 22. Implementasi halaman splash screen b. Halaman data tpq

Halaman ini menampilkan informasi data tpq, informasi yang ditampilkan pada halaman ini adalah foto, nama tpq dan alamat tpq dalam cardview. Selain itu terdapat menu pencarian dan drop menu pada sisi kanan atas. Berikut hasil implementasinya.

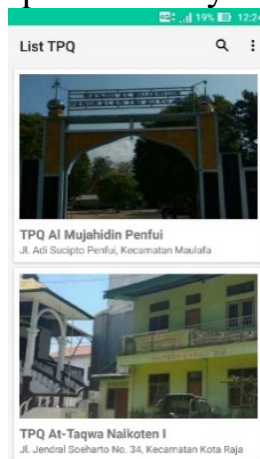

Gambar 23. Implementasi halaman data tpq c. Halaman detail tpq

Halaman ini menampilkan informasi mengenai detail data tpq, informasi ditampilkan merupakan seluruh informasi yang dimiliki untuk tpq yang dipilih. Pengguna dapat menekan tombol navigasi untuk melihat 
rute menuju lokasi. Berikut hasil implementasinya.

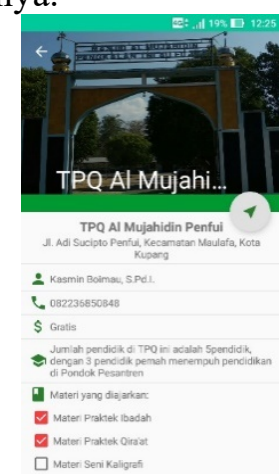

Gambar 24. Implementasi halaman detail tpq

d. Halaman pencarian tpq

Halaman ini merupakan halaman yang digunakan untuk melakukan pencarian data tpq, pengguna dapat menulis kata kunci di kolom search dan sistem akan menampilkan hasil pencarian dalam bentuk cardview. Selain itu pengguna dapat menekan cardview untuk melihat detail tpq yang dipilih. Berikut hasil implementasinya.

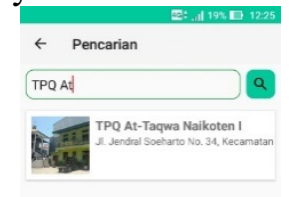

Gambar 25. Implementasi halaman pencarian tpq e. Halaman tentang aplikasi

Halaman ini menampilkan informasi mengenai aplikasi, developer, dan versi aplikasi. Selain itu jika pengguna menekan logo aplikasi sebanyak tiga kali maka akan masuk ke dalam halaman login. Berikut hasil implementasinya.

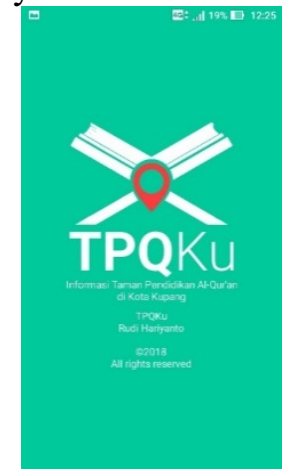

Gambar 26. Implementasi halaman tentang aplikasi f. Halaman login

Halaman login merupakan halaman yang digunakan untuk menjadi admin dan mendapatkan akses untuk mengolah data. Pengguna harus memasukan email dan password untuk mendapatkan akses admin. Berikut hasil implementasinya.

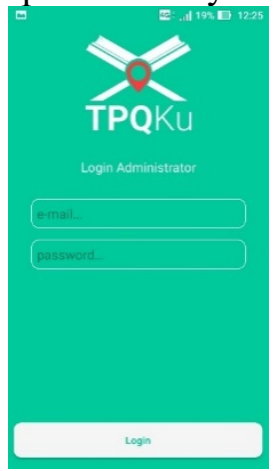

Gambar 27. Implementasi halaman login

g. Halaman tambah data tpq

Halaman tambah data tpq digunakan admin untuk menambah data tpq. Pertama admin menentukan koordinat lokasi tpq, selanjutnya mengisi data sesuai form yang ada. Setelah pengguna menekan tombol simpan maka data akan disimpan ke dalam basis data. Berikut hasil implementasinya.

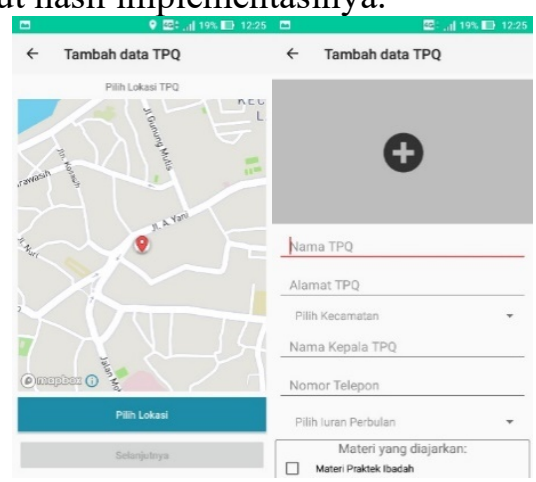

Gambar 28. Implementasi halaman tambah data tpq h. Halaman ubah data tpq

Halaman ubah data tpq digunakan untuk mengubah data tpq yang sudah pernah diinput. Data yang sebelumnya diinput akan muncul dalam form dan pengguna tinggal mengganti data yang diinginkan. Setelah itu pengguna dapat menekan tombol simpan dan sistem akan menyimpan perubahan data kedalam basis data. Berikut hasil implementasinya. 


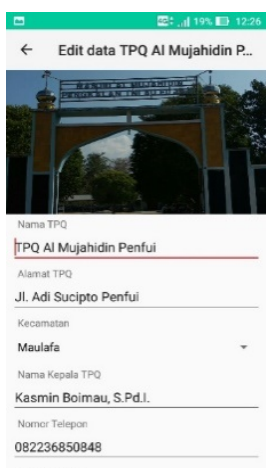

Gambar 29. Implementasi halaman ubah data tpq i. Halaman hapus data tpq

Halaman hapus data tpq digunakan admin untuk menghapus data tpq. Akan muncul halaman konfirmasi untuk menghapus data, jika pengguna menekan tombol "ya" maka sistem akan menghapus data tersebut dari basis data, sedangkan jika pengguna menekan tombol "tidak" maka sistem akan menutup halaman hapus data dan kembali ke halaman data tpq. Berikut hasil implementasinya.

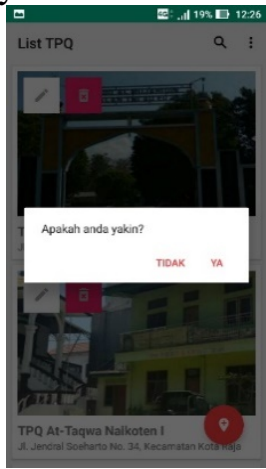

Gambar 30. Implementasi halaman hapus data tpq

\section{SIMPULAN}

\section{Simpulan}

Berdasarkan hasil analisis, implementasi dan evaluasi yang telah dilakukan pada penelitian ini, dapat disimpulkan bahwa penelitian ini telah berhasil membangun sebuah aplikasi untuk memberikan informasi mengenai Taman Pendidikan Al-Qur'an di Kota Kupang.

Aplikasi ini telah membantu memberikan informasi mengenai TPQ, mulai dari alamat, koordinat lokasi, kepala TPQ tersebut, kontak yang dapat dihubungi, gambaran lokasi, materi yang diajarkan, serta biaya yang dibutuhkan per bulan.

Pengujian penguna menunjukan bahwa $81 \%$ pengguna tingkat akhir merespon sangat positif terhadap keberadaan aplikasi dan menerimanya sebagai aplikasi yang dapat membantu untuk memberikan informasi mengenai TPQ di Kota Kupang.

Saran

Penelitian ini tidak luput dari kesalahan dan kekurangan. Bagi peneliti selanjutnya yang ingin mengembangkan penelitian ini dapat kiranya menambahkan beberapa kriteria berikut untuk kesempurnaan aplikasi:

1) Mengurangi ketergantungan terhadap internet dengan menggunakan basis data yang dapat diakses tanpa akses internet, tetapi tetap dapat mengupdate data terbaru.

2) Memperluas jangkauan data dari Kota Kupang menjadi Nusa Tenggara Timur ataupun Indonesia.

3) Memperkaya fitur serta variasi data sehingga dapat menyajikan lebih banyak informasi

\section{DAFTAR PUSTAKA}

[1] Badan Pusat Statistik Kota Kupang. 2014. Data Banyaknya Penduduk Kota.

[2] Hartono, Foeng. Sevai, Nina. 2013. Aplikasi Navigasi Lokasi Pom Bensin Di Jakarta Berbasis Android. Jakarta (ID): Universitas Kristen Krida Wacana.

[3] Igfar, Muhammad. 2017. Aplikasi Pencarian Lokasi Hotel Berbasis Android (Studi Kasus: Kota Kupang). Kupang (ID): Stikom UYELINDO. 